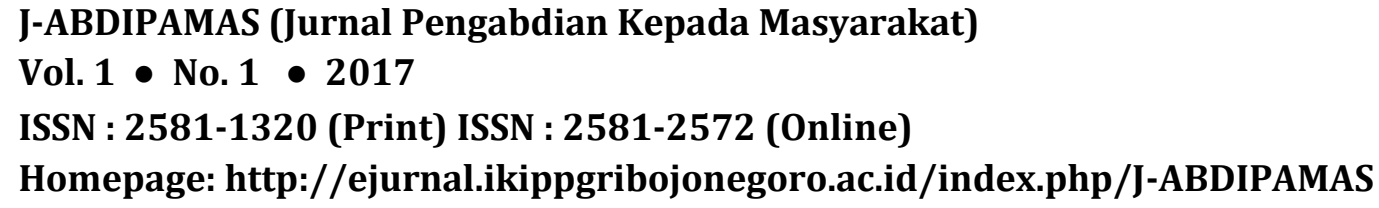

ISSN : 2581-1320 (Print) ISSN : 2581-2572 (Online)

Homepage: http://ejurnal.ikippgribojonegoro.ac.id/index.php/J-ABDIPAMAS

\title{
CAPACITY BUILDING GURU RA ASY-SYAFI'IYYAH PEKALONGAN JEPARA MELALUI EDUKASI APE SOFT-BOOK (BUKU BANTAL) BERBAHASA INGGRIS DARI SPONS ATI
}

\author{
Santi Andriyani, ${ }^{1}$, Aliva Rosdiana ${ }^{2}$, dan Ariyanto $^{3}$ \\ ${ }^{1}$ Universitas Islam Nahdlatul Ulama' Jepara. Email : santiandriyani6@gmail.com \\ ${ }^{2}$ Universitas Islam Nahdlatul Ulama' Jepara. Email : alivarosdiana1983@gmail.com \\ ${ }^{3}$ Universitas Islam Nahdlatul Ulama' Jepara. Email : ian.armiena@gmail.com
}

\begin{abstract}
Educational Gaming Device, or Alat Peraga Edukatif (APE) is a media which should be mastered by teachers in teaching learning activities for young learners. By using APE, it gives advantages for children in developing their motoric abilities, concentrations, and also their ability in language and knowledge. Based on the result of observation and interview to one of teachers in RA Asy-Asfi'iyyah in Pekalongan Jepara, the priority of problems is the weakness of teachers in creating APE. The aim of this community service activity was to give training skills to teachers dealing with APE specifically in creating English soft-book from sponge sheet. The method used was preparation, implementation, and evaluation. The results of this dedication are: (1) the teachers know the strategy of how to teach joyful learning (2) the teachers were also able to make English soft-book well through four steps, i.e drawing, cutting, sticking, and compiling become a book, (3) the teachers are able to apply the APE in teaching and learning processess.
\end{abstract}

Keywords: Capacity Building, Teachers of Kindergarten, Young Learners, Educational Gaming Device, soft book.

\begin{abstract}
ABSTRAK
Alat peraga edukatif (APE) merupakan media yang harus dikuasai oleh guru dalam proses belajar mengajar bagi anak usia dini. Dengan menggunakan APE, maka akan memberikan manfaat bagi anak yaitu melatih motorik, melatih konsentrasi, dan juga melatih bahasa dan wawasan anak. Berdasarkan hasil observasi dan wawancara dengan salah satu guru RA Asy- Asyfi'iyyah di desa Pekalongan, maka prioritas permasalahan adalah lemahnya guru dalam membuat APE. Tujuan dari pengabdian ini adalah memberikan keterampilan kepada guru mengenai APE berupa buku bantal berbahasa Inggris dari spons ati. Adapun metode pelaksanaanya adalah mulai tahapan persiapan, pelaksanaanya sampai evaluasi. Hasil dari pengabdian ini adalah: (1) para guru mendapatkan pengetahuan mengenai strategi mengajar yang menyenangkan; (2) para guru juga dapat membuat buku bantal berbahasa Inggris dengan baik melalui tahap menggambar, menggunting, menempel, dan menyusun buku; dan (3) para guru dapat mengaplikasikan APE tersebut dalam pembelajaran di kelas.
\end{abstract}

Kata Kunci: Capacity building, Guru RA, Anak usia dini, Alat peraga edukatif, Buku bantal.

\section{PENDAHULUAN}

Pendidikan usia dini merupakan wahana pendidikan yang sangat fundamental untuk berkembangnya dasar-dasar pengetahuan, sikap/perilaku dan keterampilan pada anak. Keberhasilan proses pendidikan pada masa tersebut menjadi dasar untuk proses pendidikan selanjutnya. Keberhasilan penyelenggaraan pendidikan pada lembaga pendidikan anak dini, seperti: kelompok bermain, Taman Penitipan Anak (TPA) maupun Taman Kanak-Kanak/Raudlatul Athfal sangat bergantung pada sistem dan proses 
pendidikan yang dijalankan.

Dalam melaksanakan proses belajar mengajar untuk anak usia dini, guru hendaknya memiliki pemahaman yang baik tentang materi yang akan diberikan kepada anak dan menyiapkan alat peraga apa yang akan digunakan untuk pembelajaran di kelas. Alat peraga ini adalah salah satu sumber belajar yang sangat diperlukan untuk mengembangkan aspek-aspek perkembangan anak usia dini termasuk TK/RA.

Prinsip dasar pendekatan pembelajaran anak di TK/RA meliputi bermain sambil belajar dan belajar seraya bermain, pembelajaran berorientasi pada perkembangan anak, pembelajaran berorientasi pada kebutuhan anak, pembelajaran berpusat pada anak, pembelajaran menggunakan pendekatan tematik, pembelajaran pakem, pembelajaran mengembangkan kecakapan hidup, pembelajaran yang didukung oleh lingkungan yang kondusif, pembelajaran yang demokratis, dan pembelajaran yang bermakna (Departemen Pendidikan Nasional, 2005).

Prinsip- prinsip tersebut dapat berjalan maksimal manakala semua proses belajar mengajar yang dilaksanakan oleh guru dipersiapkan dengan sebaik-baiknya. Hal yang juga mendukung adalah Alat peraga edukatif (APE) sebagai alat penunjang untuk meningkatkan pemahaman anak dan merangsang keingintahuan anak akan sesuatu.

Alat peraga edukatif untuk anak TK/RA adalah alat yang sengaja dirancang secara khusus untuk meningkatkan aspek-aspek perkembangan anak. Menurut Suryadi (2007), bahwa alat peraga edukatif adalah alat yang dirancang khusus sebagai alat untuk bantu belajar dan dapat mengoptimalkan perkembangan anak, disesuaikan dengan usia dan tingkat perkembangannya.

Namun, tidak semua guru TK/RA memiliki keterampilan dalam membuat dan merancang APE. Ini membutuhkan kreatifitas, keinginan yang kuat, kerjasama dan inovasi dari guru tersebut. Hal ini juga dialami di desa Pekalongan Jepara.

Berdasarkan hasil need assessment yang telah dilakukan, maka persoalan yang paling krusial adalah kurangnya profesionalitas guru yang ada di desa Pekalongan dalam proses belajar mengajar terutama dalam membuat Alat peraga edukatif (APE). Metode mengajarnya hanya sebatas ceramah tanpa ada lesson plan yang terstruktur .

Hal ini juga diperkuat dengan hasil wawancara kami dengan salah satu guru TK di desa Pekalongan yang berinisial ML. Dia mengatakan bahwa kelemahan kami guru TK adalah mengenai cara mengajar dan bagaimana membuat APE. Dari hasil wawancara dan observasi menunjukkan bahwa masalah pendidikan didesa Pekalongan ada tiga yaitu banyak masyarakat yang belum sadar akan pentingnya pendidikan, guru masih banyak yang belum menguasai kurikulum, dan guru belum memiliki keterampilan membuat APE serta metode pembelajaran yang menarik dan menyenangkan.

Dari deskripsi di atas, maka disimpulkan bahwa pembuatan APE merupakan hal yang penting yang harus dilakukan oleh guru. Berdasarkan Undang-Undang Sisdiknas No.20 tahun 2013 dijelaskan bahwa kewajiban guru sebelum mereka berdiri di depan kelas adalah menciptakan suasana pendidikan yang bermakna, kreatif, dinamis, dan dialogis dan mempunyai komitmen secara profesional untuk meningkatkan mutu pendidikan.Dengan begitu, guru tidak lagi hanya sebagai pengajar tetapi lebih luas yaitu sebagai fasilitator.(Tian Belawati ,2003: 1.4 - 1.9). 
Lembaga pendidikan anak usia dini yang kami jadikan mitra adalah RA AsySyafi'iyyah desa Pekalongan kecamatan Batealit. Pemilihan mitra tersebut sesuai dengan hasil wawancara kami dengan salah satu guru yang mengajar di RA Asy-Syafi'iyyah yang berinisial Ibu SR pada tanggal 5 Februari 2016. Beliau mengatakan bahwa guru-guru yang ada di RA Asy-Syafi'iyyah masih perlu banyak belajar tentang cara mengajar yang menyenangkan. Beliau juga mengatakan bahwa APE yang digunakan di RA AsySyafi'iyyah masih sangat sedikit dan mudah rusak. Hal ini tidak sesuai dengan prinsipprinsip pembuatan APE diantaranya adalah pembuatan APE harus bervariasi dan tidak mudah rusak atau rapuh (Zaman Badru, 2007: 7-15)

Selanjutnya, data di atas juga di perkuat oleh hasil wawancara kami dengan Kepala Sekolah RA Asy-Syafi'iyyah yang berinisial AN pada tanggal 5 Februari 2016. Beliau menyampaikan bahwa di RA Asy-Syafi'iyyah jarang sekali mengikuti pelatihan-pelatihan yang berkaitan dengan peningkatan kualitas guru. Di RA tersebut juga jarang melaksanakan pelatihan secara mandiri untuk meningkatkan capacity building mereka. Beliau juga menyampaikan bahwa guru-guru di RA Asy-Syafi'iyyah belum pernah membuat APE yang menarik dan kreatif terutama dengan materi English Learning.

Dari hasil wawancara diatas, maka perlu mengadakan Edukasi dan Training dalam rangka meningkatkan kualitas dan kreatifitas para guru dengan bentuk pembuatan soft book atau buku bantal berbahasa Inggris dari spons ati.

\section{METODE PELAKSANAAN}

Dengan melihat permasalahan diatas, maka kami memberikan solusi sebagai berikut:

Tabel 1 Metode Pelaksanaan Kegiatan

\begin{tabular}{|c|c|c|}
\hline No & Tahapan & Deskripsi \\
\hline 01 & Persiapan & \begin{tabular}{ll} 
a. & \multicolumn{3}{l}{ Menganalisa semua kebutuhan untuk } \\
kemudian disiapkan agar \\
pelaksanakan berjalan \\
harapan. \\
b. Komunikasi dan koordinasi dengan \\
pihak mitra terkait dengan segala \\
administrasi dan konsep pelaksanaan \\
program.
\end{tabular} \\
\hline \multirow[t]{2}{*}{02} & Pelaksanaan & $\begin{array}{l}\text { a. Untuk memberikan motivasi kepada } \\
\text { mitra mengenai pentingnya mengajar } \\
\text { yang asyik dan menyenangkan bagi } \\
\text { anak didik, maka kami mengadakan } \\
\text { penyuluhan mengenai teknik } \\
\text { mengajar yang asik dan } \\
\text { menyenangkan bagi anak usia dini } \\
\text { b. Untuk melatih keterampilan mitra, } \\
\text { maka sebelum pembuatan buku } \\
\text { bantal, kami melaksanakan program } \\
\text { pelatihan membuat pola sebagai } \\
\text { dasar menggambar. }\end{array}$ \\
\hline & & $\begin{array}{l}\text { Program selanjutnya dalah } \\
\text { pembuatan softbook atau buku bantal } \\
\text { berbahasa Inggris dari spons ati. }\end{array}$ \\
\hline
\end{tabular}


Evaluasi kegiatan merupakan program yang harus dilaksanakan sebagai indikator keberhasilan program pengabdian tersebut. Tujuan dari evaluasi adalah untuk mengetahui sejauh mana kegiatan yang telah dilaksanakan berjalan dengan baik atau sebaliknya. Melakukan evaluasi program adalah kegiatan yang dimaksudkan untuk mengetahui seberapa tinggi tingkat keberhasilan dari kegiatan yang direncanakan (Arikunto, 1993:297).

Evaluasi merupakan hal yang penting dalam setiap program karena tujuan dari evaluasi adalah untuk mengetahui tingkat keberhasilan program yang dilaksanakan. Hal ini sesuai dengan apa yang dikemukakan oleh Endang Multiningsih (2011: 114115), evaluasi program dilakukan dengan tujuan untuk:

a. Menunjukkan sumbangan program terhadap pencapaian tujuan organisasi. Hasil evaluasi ini penting untuk mengembangkan program yang sama di tempat lain.

b. Mengambil keputusan tentang keberlanjutan sebuah program apakah program perlu diteruskan, diperbaiki, atau dihentikan.

Dalam program pengabdian ini, program evaluasi ini kami rencanakan sebanyak 2 kali. Evaluasi yang pertama adalah evaluasi untuk kegiatan tahap pertama yaitu mengenai program motivasi dan pelatihan membuat pola. Untuk evaluasi kedua kami laksanakan pada kegiatan pengabdian tahap kedua yaitu pembuatan soft-book dari spons ati. Evaluasi program ini kami laksanakan dalam bentuk brainstorming dan curah pendapat.

\section{HASIL DAN PEMBAHASAN}

Sesuai dengan tahapan kegiatan yang kami susun, maka realisasi program ini memiliki tiga tahap, yaitu persiapan, pelaksanaan, dan evaluasi.

Tahap Persiapan

Sebelum kami melaksanakan program pengabdian, kami terlebih dahulu melakukan pra survey dan analisa kebutuhan mitra. Observasi dan wawancara kami lakukan pada tanggal 31 Januari 2016 di RA Asy-Syafi'iyyah Pekalongan Batealit Jepara. Dengan melakukan need assessment terlebih dahulu, maka program pengabdian yang dilaksanakan diharapkan sesuai dengan kebutuhan RA tersebut.

Adapun hasil dari observasi dan wawancara tersebut adalah:

1. Perlu peningkatan kualitas di desa Pekalongan terutama bidang pendidikan.

2. Kurangnya profesionalitas para pendidik di RA Asy-Syafi'iyyah dalam proses belajar mengajar.

3. Kurangnya pengetahuan para pendidik RA Asy-Syafi'iyyah tentang Alat peraga edukatif yang variatif, awet dan mengembangkan kecerdasan bahasa anak.

Tahap Pelaksanaan

Kegiatan pengabdian ini dilaksanakan dengan pendekatan sosialisasi dan pendampingan pembuatan bahan ajar buku bantal (soft-book) dari spons ati. Adapun urutan kegiatannya sebagai berikut: 
Tabel 2 Metode dan Pendekatan Kegiatan Pengabdian

\begin{tabular}{|c|c|c|c|c|}
\hline No & $\begin{array}{l}\text { Aplikasi } \\
\text { Kegiatan }\end{array}$ & $\begin{array}{r}\text { Metode } \\
\text { Pendekatan }\end{array}$ & Target & Mitra \\
\hline 1 & $\begin{array}{l}\text { Memberikan } \\
\text { pengetahuan } \\
\text { tentang } \\
\text { Perencanaan, } \\
\text { dan } \\
\text { Pemanfaatan } \\
\text { Spons ati } \\
\text { sebagai APE dalam } \\
\text { pembelajaran bahasa } \\
\text { Inggris }\end{array}$ & Sosialisasi & \begin{tabular}{l}
\multicolumn{3}{l}{ Terbentuknya } \\
kelompok kreatif \\
dalam pembuatan \\
buku $r$ bantal \\
(softbook) dari \\
spons ati sebagai \\
APE bahasa Inggris.
\end{tabular} & $\begin{array}{l}\text { Menyediakan } \\
\text { tempat dan } \\
\text { hadir pada } \\
\text { kegiatan, aktif } \\
\text { dalam diskusi } \\
\text { dan tanya jawab } \\
\text { untuk hal-hal } \\
\text { yang kurang } \\
\text { dipahami }\end{array}$ \\
\hline 2 & $\begin{array}{l}\text { Memberikan } \\
\text { tutorial cara membuat } \\
\text { buku bantal (softbook) } \\
\text { dari spons ati sebagai } \\
\text { APE bahasa Inggris }\end{array}$ & Pemberian tugas & $\begin{array}{l}\text { Memahami rara } \\
\text { pembuatan buku } \\
\text { bantal (softbook) } \\
\text { dan rampu } \\
\text { menerapkannya. }\end{array}$ & $\begin{array}{l}\text { Mempraktekkan } \\
\text { cara pembuatan } \\
\text { buku bantal } \\
(\text { softbook). }\end{array}$ \\
\hline \multirow[t]{3}{*}{3} & $\begin{array}{l}\text { Mempersiapkan bahan- } \\
\text { bahandan }\end{array}$ & Pendampingan & $\begin{array}{lr}\text { Buku } & \text { bantal } \\
\text { (softbook) } & \text { sebagai }\end{array}$ & $\begin{array}{l}\text { Mitra dapat } \\
\text { mengaplikasikan }\end{array}$ \\
\hline & $\begin{array}{l}\text { perlengkapannya untuk } \\
\text { pembuatan buku bantal }\end{array}$ & & APE bahasa Inggris. & $\begin{array}{lr}\text { buku } & \text { bantal } \\
\text { (softbook) } & \text { sebagai }\end{array}$ \\
\hline & $($ softbook) & & & $\begin{array}{l}\text { Media Belajar yang } \\
\text { menarik. }\end{array}$ \\
\hline
\end{tabular}

Untuk mendapatkan hasil yang optimal, maka kami juga melibatkan narasumber yang sudah ahli di bidang pendidikan mengenai teknik mengajar yang menyenangkan bagi anak usia dini. Materi pelatihan secara secara umum meliputi pemahaman teori pengajaran anak usia dini, kreatifitas stakeholder (guru), dan ketrampilan membuat buku bantal (soft-book).

Adapun urutan kegiatan pelaksanaan pengabdian pembuatan buku bantal (softbook)sebagai bahan ajar dalam pembelajaran bahasa Inggris adalah sebagai berikut:

Tabel 3 Deskripsi Kegiatan Pengabdian

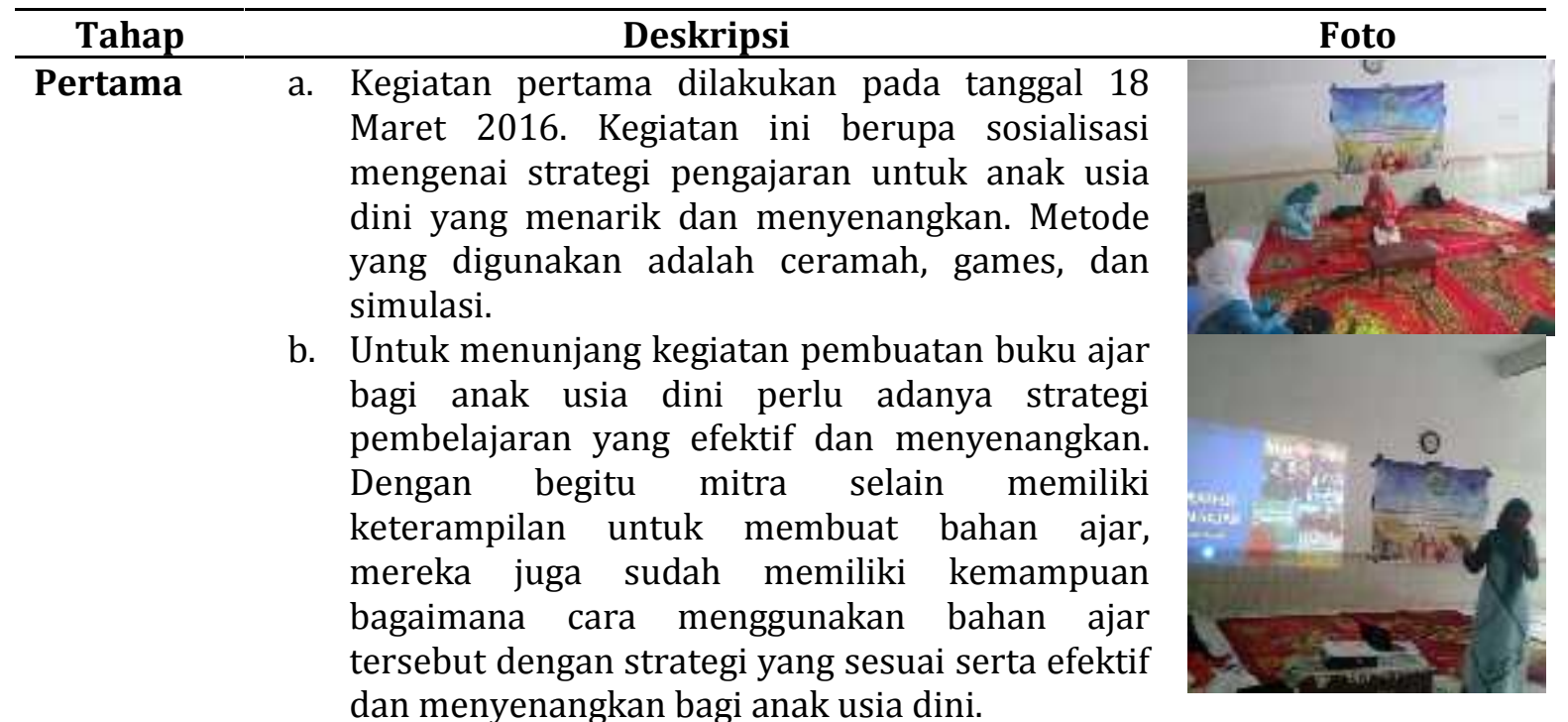




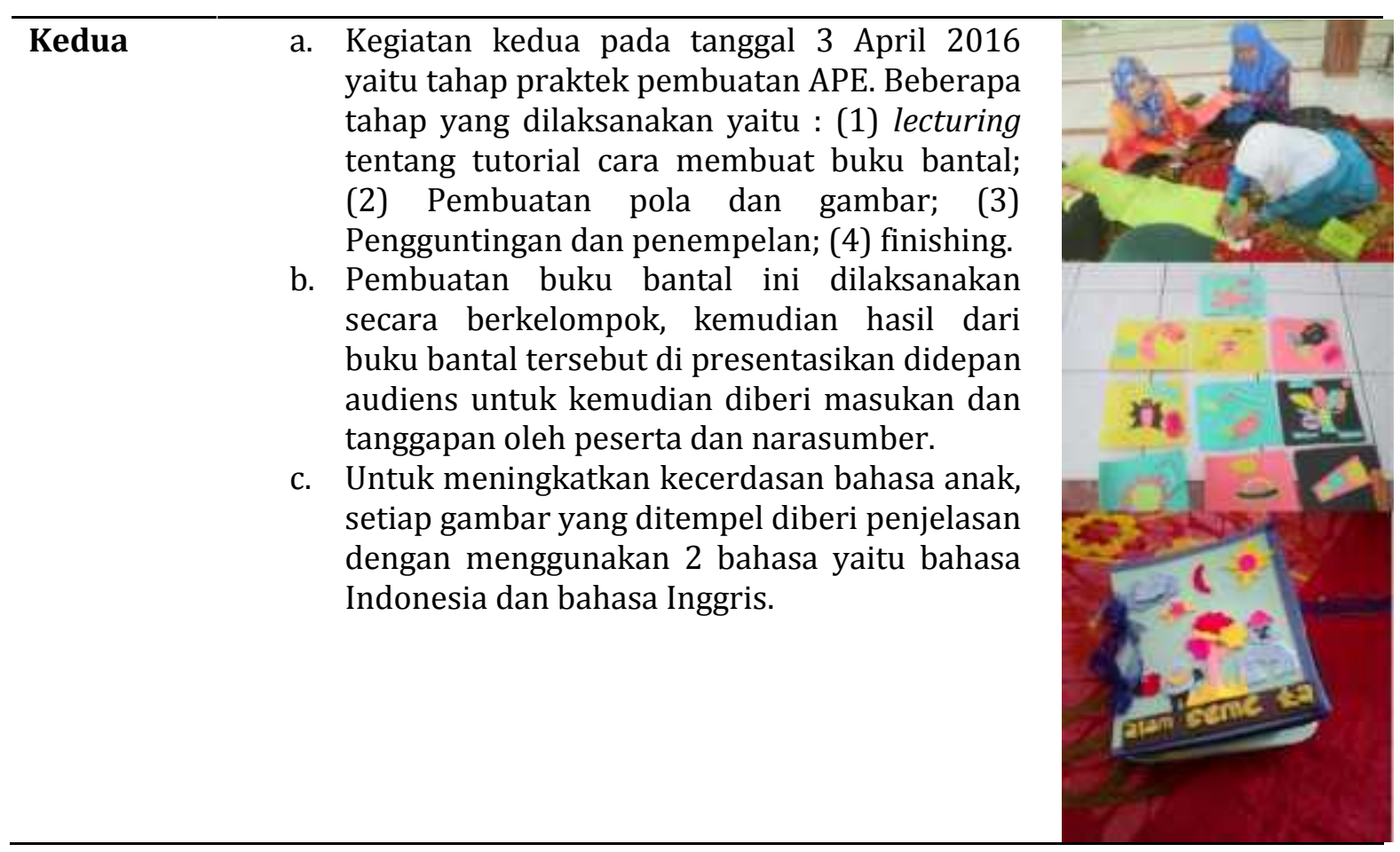

\section{Tahap Evaluasi Kegiatan}

Dalam program pengabdian ini, program evaluasi ini kami laksanakan sebanyak 2 kali. Evaluasi yang pertama yaitu pada tanggal 18 Maret 2016 saat kegiatan tahap pertama yaitu mengenai program motivasi dan startegi pembelajaran bagi anak usia dini yang efektif dan menyenangkan.

Bentuk evaluasi yang dilakukan adalah dalam bentuk brainstorming dan informal. Kami hanya saling curah pendapat antara pelaksana program dan peserta mengenai hal-hal yang berkaitan hasil program yang baru saja dilaksanakan, seperti asas kebermanfaatan, kekurangan, dan masukan.

Hasil dari brainstrorming pertama menunjukkan hasil yang positif. Para peserta merasa antusias dan memahami materi yang disampaikan bahkan langsung melakukan simulasi pada saat pelatihan.

Evaluasi kedua dilakukan pada tanggal 03 April 2016 setelah melaksanakan program yang kedua yaitu pembuatan APE dari spons ati. Bentuk evaluasi yang dilakukan sama dengan program pertama yaitu menggunakan brainstorming. Hasil dari evaluasi tersebut adalah para peserta mampu membuat APEsecara berkelompok . Untuk kontiyuitas program, kami fasilitasi bahan-bahan untuk membuat buku ajar tersebut untuk kemudian bisa dipraktekkan di sekolah maupun dirumah. Adapun hasilnya adalah tiap guru telah membuat bahan ajar dari bahan-bahan yang disediakan.

\section{SIMPULAN}

Dari hasil pengabdian masyarakat tersebut, ada beberapa hal yang menjadi kesimpulan yaitu:

1. Kegiatan pengabdian ini terbagi menjadi dua tahap. Tahap pertama tentang sosialisasi strategi pembelajaran yang efektif dan menyenangkan bagi anak usia 
dini. Tahap yang kedua adalah pembuatan APE buku bantal berbahasa Inggris dari spons ati.

2. Mitra dari pengabdian ini sangat antusias dan semangat untuk mengikuti kegiatan kegiatan tersebut terbukti dari banyaknya pertanyyan dan curah pendapat. Selain itu, setelah praktek pembuatan buku bantal selesai mitra juga dengan penuh semangat membuat bahn ajar selanjutnya disekolah.

3. Evaluasi kegiatan ini berbentuk brainstorming dengan saling bertukar pikiran halhal yang menjadi factor pendukung dan penghambat dalam kegiatan ini.

Adapun saran program pengabdian masyarakat ini sebagai berikut:

1. Perlu adanya tambahan mitra karena di desa Pekalongan banyak sekolah-sekolah baik TK dan RA yang juga membutuhkan skill tersebut.

2. Perlu adanya tindak lanjut sehingga hasilnya dapat lebih comprehensive.

\section{DAFTAR RUJUKAN}

Arikunto,Suharsimi. (1993). Manajemen Penelitian. Jakarta: PT Grafindo Persada.

Depdiknas. (2005). Pedoman Pembelajaran di Taman Kanak-Kanak. Jakarta: Direktorat Pembinaan Taman Kanak-Kanak Sekolah Dasar.

Mulyatiningsih, Endang. (2011). Metode Penelitian Terapan Bidang Pendidikan. Yogyakarta: Alphabeta.

Suryadi. (2007). Cara Efektif Memahami Perilaku Anak Usia Dini. Jakarta: EDSA Mahkota. Tian, Belawati, dkk. (2003). Pengembangan Bahan Ajar. Jakarta: Pusat Penerbitan UT. Zaman, Badru,dkk. (2007). Media dan Sumber Belajar TK. Jakarta: Universitas Terbuka. 